\title{
A NEW TECTONOMETAMORPHIC MAP OF THE CANADIAN SHIELD: INTRODUCTION
}

\author{
ROBERT G. BERMAN ${ }^{\S}$ \\ Continental Geoscience Division, Geological Survey of Canada, 615 Booth Street, Ottawa, Ontario K1A OE8, Canada
}

R. MICHAEL EASTON

Precambrian Geoscience Section, Ontario Geological Survey, 933 Ramsey Lake Road, Sudbury, Ontario P3E 6B5, Canada

\author{
LÉOPOLD NADEAU
}

Centre géoscientifique de Québec, 880, chemin Sainte-Foy, Case postale 7500, Ste-Foy, Québec G1V 4C7, Canada

\begin{abstract}
In this introduction, we briefly describe the project to produce a new tectonometamorphic map of the Canadian Shield. The design of the legend differs from that of traditional metamorphic maps by visually emphasizing differences in metamorphic ages, grade, as well as pressure regime. A web site has been established to facilitate the digital distribution of a 1:3,000,000 scale map of the Shield, in addition to 1:1,000,000 and 1:2,000,000 scale regional maps. Associated P-T, geochronological, and metamorphic assemblage databases for different parts of the Shield also are available. The legend design is illustrated with a simplified version of the 1:2,000,000 scale tectonometamorphic map of the Grenville Province in Quebec and Labrador, for which a brief summary is provided.
\end{abstract}

Keywords: tectonometamorphic map, Canadian Shield.

\section{SOMMAIRE}

Dans cette introduction, nous décrivons brièvement le projet de produire une nouvelle carte tectonométamorphique du Bouclier Canadien. L'organisation de la légende diffère de celle des cartes métamorphiques traditionnelles en distinguant visuellement les ages de métamorphisme, le degré de métamorphisme, de même que le contexte de pression. Nous avons établi un site web afin de faciliter la distribution des cartes du Bouclier en entier (1:3,000,000) et de régions plus restreintes $(1: 1,000,000$ ou 1:2,000,000) dans un format digital. Les banques de données associées, par exemple sur les pressions et températures déterminées, les datations et les assemblages métamorphiques, sont aussi disponibles pour les diverses parties du Bouclier. Le concept de la légende est illustré au moyen d'une version simplifiée de la carte tectonométamorphique (1:2,000,000) de la Province du Grenville au Québec et au Labrador, dont on donne ici un bref aperçu.

(Traduit par la Rédaction)

Mots-clés: carte tectonométamorphique, Bouclier Canadien.

\section{INTRODUCTION}

The first metamorphic map of the Canadian Shield was published in 1978 (Fraser et al. 1978), and, together with a compendium of related papers (Fraser \& Heywood 1978), has remained the only major source showing the distribution of metamorphic facies for most parts of the Canadian Shield. Since the publication of this map, there have been significant advances in understanding the relationship between metamorphism and tectonics, as well as in developing geochronological and petrological techniques needed to characterize better the timing and physical conditions of metamorphic events. In order to appreciate the impact of these advances on understanding the tectonometamorphic history of the Canadian Shield, a new tectonometamorphic map of the Canadian Shield has been prepared (R.G. Berman, in prep.) with the help of numerous people and organizations listed on the map. Here, we present a brief overview of this project, including the main products, a summary of key mineral reactions used to define most metamorphic facies (Fig. 1), a description of the design of the map legend (Fig. 2), a simplified tectonometamorphic map of the Grenville Province in Quebec and

§E-mail address: rberman@nrcan.gc.ca 


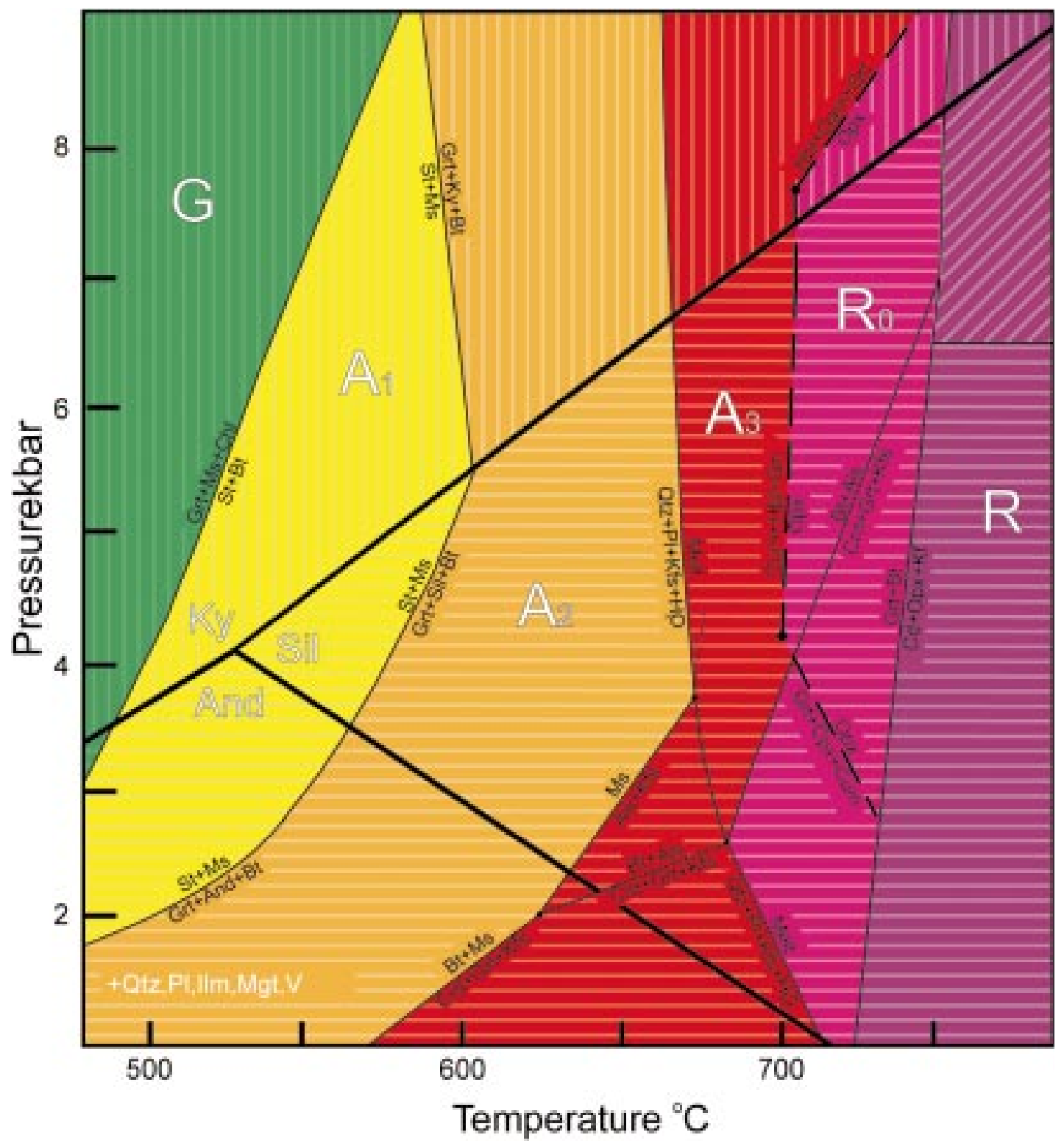

FIG. 1. Key mineral reactions defining metamorphic zones. Solid and dashed curves refer to reactions in potassic and calcic bulk compositions, respectively.

Labrador (Fig. 3) that illustrates the legend design, and a brief summary of this region.

\section{Products}

The tectonometamorphic map of the Canadian Shield project has a number of products. The map, which includes Greenland, has been prepared at
$1: 3,000,000$ scale, along with two larger-scale maps showing Archean-only and Proterozoic and younger metamorphism. Also available are regional maps at 1:1,000,000 scale (Manitoba, Ontario, Saskatchewan, Greenland, Slave Province) and 1:2,000,000 scale (Grenville Province). Maps for other regions or at different scales are available on special request. Distribution of the maps and associated databases 
(geochronology, P-T data, point-source data on mineral assemblages) is provided primarily by internet access (http://gis.NRCan.gc.ca/metmap/index4.htm). It is anticipated that this form of distribution will facilitate the exchange of information that can be used to update these maps periodically.

\section{LEGEND}

The legend used for this map differs considerably from that of most metamorphic maps, which have generally used legends similar to that of Zwart (1973). These legends show polymetamorphic relationships with hatched linework, but they in general do not graphically depict metamorphic age-relations, nor do they distinguish pressure regimes. In order to enhance the tectonic value of the new map, its legend utilizes a new scheme for graphical representation of metamorphic age, metamorphic grade, as well as pressure regime. We do not employ more recent tectonometamorphic classifications based on $\mathrm{P}-\mathrm{T}-\mathrm{t}$ paths (e.g., Brown 1993) owing to limitations of the available data across the Canadian Shield. Because metamorphic and age relations are both depicted, the legend is necessarily complex; users of the new map will need to become acquainted with the design of this legend before they can take full advantage of all the information portrayed. In order to facilitate this process, we provide below a description of the design of this legend.

For the purposes of illustration of the legend design within the size limitations of this journal's format, we show a version of the legend (Fig. 2) used for the 1:2,000,000 scale tectonometamorphic map of the Grenville Province in Quebec and Labrador (Fig. 3). The only difference between this legend and those applied to the Canadian Shield and other regional maps is the number and identity of the different metamorphic ages used for each region. For example, Easton (2000b) shows a legend with the different metamorphic ages used in Ontario.

Twelve metamorphic grades are used, ranging for the most part from cool to warm colors with increasing grade. For each metamorphic event, only the peak metamorphic grade is shown. Most metamorphic facies are defined by reactions (Fig. 1) taken from a petrogenetic grid for pelitic rocks constructed by D.M. Carmichael (Davidson et al. 1990), with additional amphiboleorthopyroxene reactions from Froese (1997). Definitions of subgreenschist, greenschist, amphibolite, albite-epidote amphibolite (high-P amphibolite), blueschist, and eclogite facies in mafic rocks are based on a petrogenetic grid derived by Evans (1990). A complete description of mineralogical criteria used to determine metamorphic grade is given in the marginal notes of the Shield metamorphic map (R.G. Berman, in prep.). Because more emphasis has been placed on visually conveying age relationships, two mixed grades (greenschist - lower amphibolite and upper amphibolite - granulite) have been used to represent different levels of information, including (a) regions with uniform, but transitional metamorphic grade, (b) regions with varied metamorphic grade, (c) regions with uncertain metamorphic grade. Igneous charnockites are shown separately from other granulite-facies rocks. For unmetamorphosed rocks, igneous charnockites, and plutonic bodies that have largely escaped penetrative deformation and metamorphism, relative age is conveyed with a gradational grey scale from light (young) to dark (old).

Two different series of colors are used to distinguish between Archean metamorphism and $>1760 \mathrm{Ma}$ Paleoproterozoic metamorphism (younger metamorphic ages are discussed below), shown in the last two columns of Figure 2 as a series of bright colors (age abbreviation $=26$ ) and pastel colors (age abbreviation $=18$ ), respectively. Within each color (age) series, lines of the opposite color series are used to indicate pressure regimes: horizontal (low-P), vertical (high-P), horizontal and vertical hatching (undivided; unknown). These pressure distinctions represent the classic Abukuma (low-P/T) and Barrovian (intermediate-P/T) faciesseries, respectively; the "subduction zone" (high-P/T) series that forms a very minor component of the Canadian Shield is represented with blueschist and eclogite facies. For granulite-facies rocks, a separate "intermediate-P" category ( 6.5-8.5 kbar; depicted with diagonal lines on Figures 1-3) is introduced, mainly on the basis of application of thermobarometric data.

Younger metamorphic ages, which occur primarily in the Grenville Province, are depicted (Fig. 2) with a pattern of alternating bright and white lines (age abbreviation $=14$ ) or pastel and white lines (age abbreviation $=10$ ). The orientation of lines indicates the pressure regime, as described above. Further distinctions with regard to age within the above groups (e.g., 1190-1750 Ma and <1190 Ma, Fig. 2) are made with thinner lines at right angles to the pressure lines, or oriented at $45^{\circ}$ where there is no pressure information. Where there is significant uncertainty as to age, dashed (e.g., age abbreviation $=$ Y, Fig. 2) or dotted lines are used. The number of different metamorphic ages varies with the map scale. The Shield map utilizes nine age divisions (in geons): 9-13, 14-16, 16-17.5, 17.6-18.6, 18.8-20, 25-25.7, 25.8-26.8, 26.8-28, >28. Smaller scale maps use a somewhat more detailed breakdown of ages. For example, the legend for the Grenville Province (Fig. 2) includes the following age distinctions (in geons): $<10.2,10.2-10.8,11.2-11.9,11.9-12.5,13.5-15.1,16$ $17.5,10-16,17.6-18.6$, and 25.8-26.8.

Polymetamorphism is represented with circles superimposed on the background pattern described above. The background shows the dominant metamorphism: that which is the most visible on the ground, the most evident from geochronology, or that considered to be the most important tectonically. Each circle contains the same grade, age, and pressure information as the background. In rare situations where more than two 


\section{GRENVILLE METAMORPHIC MAP LEGEND}

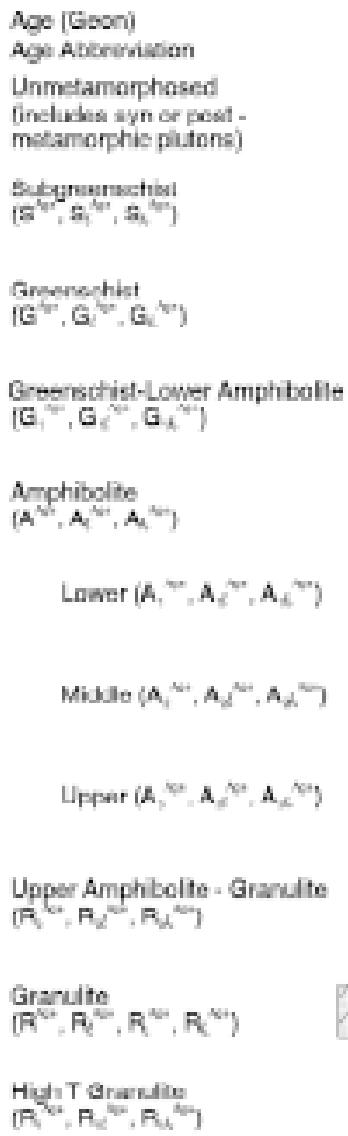

Chamockiteindertite
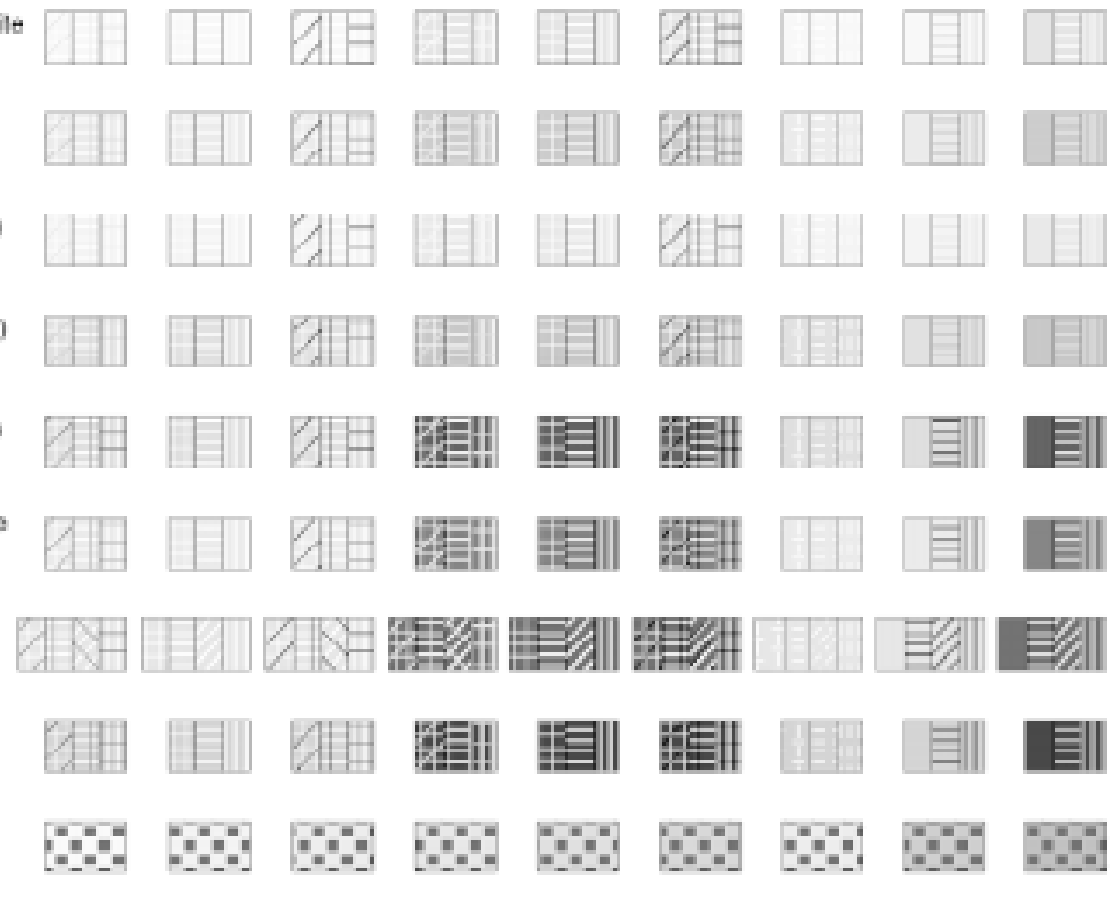

Eclogie

$\left(E^{-1} ; E^{*} ; E^{n *}\right)$
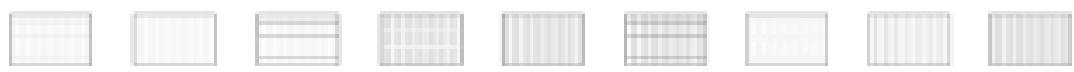

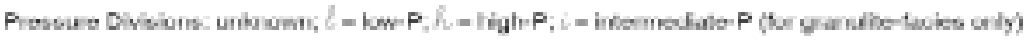

Polymetamorphisen: Background shows dominses evert, cirches show secend evem usirg above preasurs, age parterrs

Examplos:
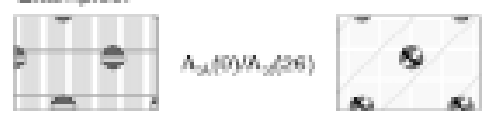

G. (90)R (16)

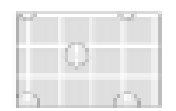

A $\{10 \% R, M)$

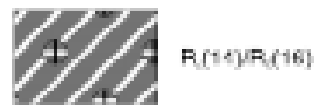

Uthetogr

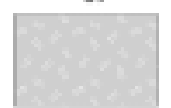

Anarthosite

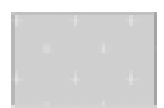

Granise

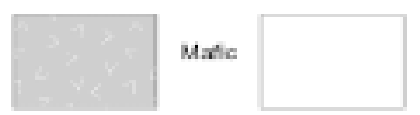

Unmelarnorphoeed corer (C5.7 Geon)

FIG. 2. Legend for the simplified tectonometamorphic map of the Grenville Province in Quebec and Labrador (Fig. 3). The legend is presented as a matrix showing metamorphic grade and metamorphic age. For each metamorphic grade and age, the orientation of the linework depicts the pressure regime. 


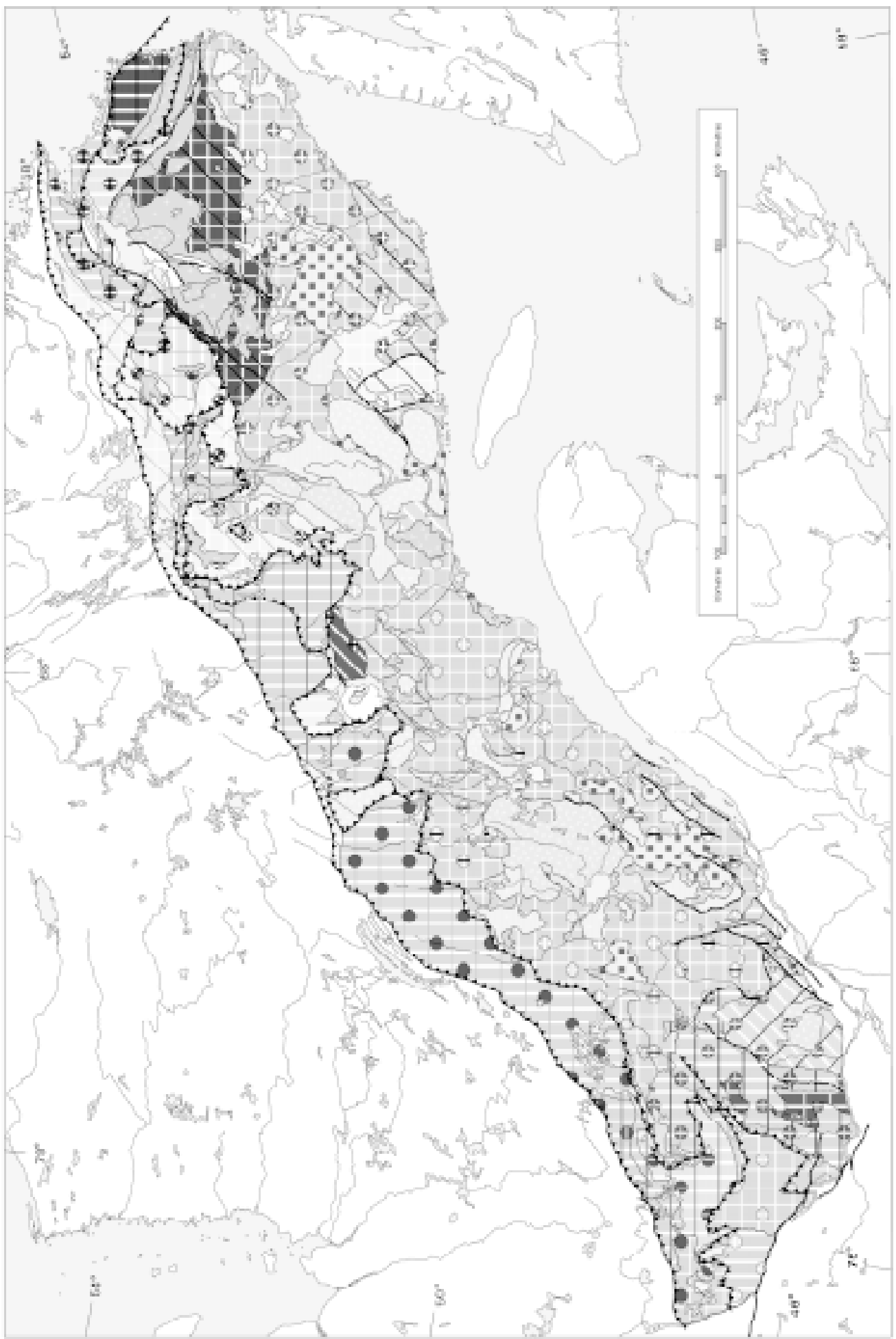

FIG. 3. Simplified tectonometamorphic map of the Grenville Province in Quebec and Labrador. 
metamorphic events can be recognized over a significant area, additional circles are added adjacent to the first. Examples of polymetamorphic patterns used in the Grenville map are illustrated in the legend (Fig. 2). A more comprehensive and concise representation of overprint patterns accompanies the complete 1:2,000,000 scale map. In regions where there is considerable uncertainty regarding overprinting relationships, smaller overprint circles are used.

Also portrayed on the new map (where data are available) are: (1) lithological information, (2) pre-, syn-, and post-metamorphic pluton suites, in order to better illustrate relationships between metamorphism and plutonism, and (3) plutons with documented contact-metamorphic aureoles, even though the aureoles themselves are too small to illustrate at the published map-scales.

\section{The Tectonometamorphic MaP}

The most significant advances in understanding the tectonometamorphic evolution of the Canadian Shield have come not as much from improved delineation of metamorphic zones, which in many places have not changed dramatically from the 1978 map, but from the greatly expanded geochronological database, which has allowed definition of 12 different metamorphic events of regional extent (see above). Application of the legend described above to the Canadian Shield allows for visual depiction of these different metamorphic events, as well as the pressure regime characteristic of each. Separate maps showing Archean-only and youngerthan-Proterozoic-only metamorphism eliminate most overprint patterns, and further facilitate interpretation of metamorphic relationships. At present, the most significant impediment to constructing a more complete metamorphic map is the limited availability of linked geochronological and metamorphic data for many parts of the Canadian Shield, a problem that is particularly acute in polymetamorphic regions. Significant advances can be expected in the near future from application of in situ dating techniques that provide a means of dating specific metamorphic minerals and associated fabrics, and establishing reliable $\mathrm{P}-\mathrm{T}-\mathrm{t}$ characteristics (e.g., Stern \& Berman 2000, Williams et al. 1999).

For summaries and discussion of large-scale (e.g., tectonic province) tectonometamorphic features, see Easton (2000a) for the Superior Province in Ontario, Easton (2000b) for the Grenville Province in Ontario, and Berman (in prep.) for other regions. Detailed summaries and discussions of specific areas can be found in many of the papers in this volume (see Preface), as well as the first volume of this series (The Canadian Mineralogist, volume 35, October issue). As an accompaniment to the simplified 1:2,000,000 metamorphic map presented here (Fig. 3), highlights of the tectonometamorphic map of the Grenville Province in Quebec and Labrador are briefly summarized below.

\section{The Grenville Province in Quebec and Labrador}

The Grenville Province of the southeastern Canadian Shield contains a remarkable extent of polymetamorphosed, high-grade, complexly deformed rocks that record the late Paleo- and Mesoproterozoic tectonic history of a large segment of the Laurentian margin. The tectonometamorphic map portrays the province as a mid- to deep-level crustal section dominated by granulite- and upper-amphibolite-facies gneiss and migmatite, invaded by voluminous anorthosite - mangerite charnockite - granite (AMCG) complexes of varied ages. In contrast, the lowest-grade upper-greenschistfacies rocks are restricted to the Hastings region of southeastern Ontario (e.g., Carmichael et al. 1978, Easton 2000b) and to the Wakeham Supergroup of eastern Quebec (e.g., Martignole et al. 1994). The profusion of AMCG plutonic complexes and the paucity of low-grade rocks (i.e., below upper-amphibolite facies) distinguish the Grenville Province from all other Precambrian terranes of the Canadian Shield.

In addition to reworked Archean greenstone belts and Paleoproterozoic passive-margin sequences that have been locally traced well within the Grenville Province, regionally extensive orogenic events made significant contributions to the Grenville's crust during the 1.7-1.6 Ga (Labradorian), 1.51-1.45 Ga (Pinwarian), 1.45-1.38 Ga (Montauban - La Bostonnais), 1.25-1.19 Ga (Elzevirian), 1.19-1.12 Ga ( Shawinigan), 1.08-1.02 (Ottawan), and 1010-960 Ma (Rigolet) time windows [cf. Davidson (1995, 1998a) and Rivers (1997) for comprehensive reviews]. Many of these events were accompanied or followed by the emplacement of large AMCG complexes, namely at 1.65-1.63 Ga (Mealy Mountains, White Bear Arm), 1.35 Ga (Rivière-Pentecôte, Whitestone), 1.16-1.13 Ga (Parry Island, Morin, Marcy, Lac Saint-Jean, Havre Saint-Pierre, Atikonak), $1.08 \mathrm{Ga}$ (Saint-Urbain), and 1.01 Ga (Labrieville) (cf. Martignole 1996).

Each of these orogenic and plutonic events has variously contributed to the regional make-up of the crust of the Grenville Province, and to the complex, overprinting deformation and metamorphic relationships that are one of the hallmarks of its high-grade gneiss. Given the complex tectonic history outlined above, it must be stressed that in most of the province, metamorphic textures and parageneses, as well as ductile deformation, cannot a priori be attributed to a Grenvillian (1.3-0.95 Ga) origin. These pre-Grenvillian metamorphic and plutonic rocks were last reworked and deeply exhumed during the Grenvillian Orogeny (sensu lato). The latter embraces a range of tectonic events beginning at $\sim 1.3 \mathrm{Ga}$ with an early accretionary stage involving ocean closure and continent-continent collision at $\sim 1.2 \mathrm{Ga}$, with attendant crustal shortening and thickening, terminating with relative rapid exhumation shortly after 1.0 Ga (Davidson 1998a). 
The new metamorphic map is largely based on, and is a complement to, the most recent geological compilation map of the Grenville Province by Davidson (1998b). It embraces current regional tectonic interpretations as initially outlined in the landmark paper of Rivers et al. (1989), who systematically described and divided the Grenville orogen into three first-order orogen-parallel belts: 1) the Parautochthonous Belt, comprising upgraded and tectonically reworked Archean and Paleoproterozoic rocks that are demonstrably related to rocks in the adjacent foreland, 2) a central Allochthonous Polycyclic Belt, composed of Late Paleoproterozoic and Mesoproterozoic terranes and rocks with a pre-Grenvillian metamorphic history, and 3 ) an outboard and discontinuous Allochthonous Monocyclic Belt, with rocks showing evidence of having been formed and metamorphosed only during the Grenvillian orogenic cycle $(<1.3 \mathrm{Ga})$. These belts are set apart by three first-order southeast-dipping crustal-scale ductile thrust zones with northwest- to north-directed tectonic transport: the Grenville Front, the Allochthon Boundary Thrust, and the Monocyclic Belt Boundary Zone. Each first-order belt comprises smaller tectonic entities bounded by kinematically compatible ductile shear zones. A strong metamorphic connotation is entrenched in these definitions (Rivers et al. 1989): the complexity and age of the metamorphic overprinting relationships are expected to decrease outboard from the Parautochthonous Belt, with some major breaks in metamorphic history occurring across first-order tectonic boundaries. Indeed, the map shows a distribution of metamorphic zones that corresponds in many places to lithotectonic terranes. This is not surprising, as the latter were defined on the basis of contrasting assemblages, structural style, metamorphic grade, etc. In addition, many shear zones defining terrane boundaries, either compressional or extensional, are late-orogenic, transposing ductile structures formed at the peak of metamorphism in their immediate footwall and hanging wall, as well as juxtaposing rocks and terranes with different earlier histories of peak metamorphism and cooling.

The new tectonometamorphic map emphasizes the diachronous and poly-orogenic nature of the provincewide high-grade metamorphic overprint. For example, although upper-amphibolite and granulite-facies metamorphism in much of Labrador occurred $\sim 1.65$ Ga during the Labradorian orogeny (e.g., Gower et al. 1991, Connelly \& Heaman 1993), comparable conditions of metamorphism were attained much later, between 1.25 and $1.16 \mathrm{Ga}$, in younger terranes of central and southwestern Quebec (e.g., Corriveau \& van Breemen 2000, Friedman \& Martignole 1995). In contrast, the effects of Grenvillian metamorphism are minimal in some of these terranes, ranging from middle-greenschist to middle-amphibolite facies, where they are mainly localized in bounding ductile shear zones (e.g., Scott et al. 1993, Corrigan et al. 2000). Following the Labradorian orogeny, most of the eastern Grenville Province appears to have been affected by medium- to high-grade Pinwarian ( 1.51-1.45 Ga) metamorphism (Wasteneys et al. 1997, Gower 1996). Metamorphic grade as low as the middle-greenschist facies occurs in some of the wellpreserved supracrustal rocks of the Wakeham Supergroup (Martignole et al. 1994). Although largely obscured by the high-grade Grenvillian overprint, highgrade metamorphism of Archean age is well documented in the parautochthon of southwestern Quebec (e.g., Childe et al. 1993). Metamorphism of Labradorian and Pinwarian age has locally been recognized in the central and northern Georgian Bay region of Ontario (e.g., Ketchum et al. 1994, Corrigan et al. 1994), as shown by Easton (2000b).

The recent documentation by Krogh (1994) that the Parautochthonous Belt adjacent to the Grenville Front is characterized along most of its length by remarkably consistent Grenvillian metamorphic ages ( $990 \mathrm{Ma})$ and moderate- to high-pressure mineral assemblages, in spite of variable uplift of the crust, suggests a systematic temporal zonation of metamorphic $\mathrm{P}-\mathrm{T}$ conditions along, and across, the orogen. The reconstruction in space and time of this zonal arrangement is hindered, however, by the scarcity of adequate geochronological and thermobarometric data and by late orogenic extensional faulting and differential uplift. Nonetheless, highpressure rocks locally containing eclogitic parageneses occur much further inboard from the Grenville Front, namely in the Georgian Bay - Algonquin (Davidson 1990) and Temiskaming (Indares \& Dunning 1997) regions, in the Manicouagan imbricate zone, and in Molson Lake terrane (Indares et al. 1998). These eclogitic and high-pressure rocks occur along deeply rooted ductile shear zones locally corresponding to the Allochthon Boundary Thrust.

The map also emphasizes the importance of AMCG complexes and, in particular, those of the voluminous 1180-1120 Ma event that are spread throughout the Allochthonous Polycyclic Belt, from the Marcy Complex of the Adirondacks Highlands, to the Atikonak and Havre-Saint-Pierre complexes of eastern Quebec. There is compelling structural evidence throughout the province suggesting that AMCG magmatism closely succeeded an early phase of Grenvillian crustal thickening, and was accompanied and followed by renewed highgrade metamorphism and deformation. Although the tectonic role of AMCG magmatism remains subject to debate (e.g., Martignole 1996, Corrigan \& Hanmer 1997), the widespread emplacement of these complexes signals the development during Grenvillian time of subcontinental-scale mantle thermal disturbances that have had a direct impact on the thermal regime of the Grenvillian crust and, hence, the nature of regional metamorphism.

The considerable progress made in our understanding of the tectonic development of the Grenville Province since the publication of the 1978 metamorphic map is anchored to regional and detailed structural stud- 
ies coupled with geothermobarometry, and above all, to the application of precise $\mathrm{U}-\mathrm{Pb}$ dating of igneous and metamorphic minerals. Such well constrained studies unfortunately remain too few and far between, leaving considerable room for interpretation. Hence, as depicted on the new map, the present metamorphic picture is likely to be profoundly modified in regions where new structural and metamorphic data become available. In spite of this, however, the new map provides a significant step toward the goal of producing a comprehensive and tectonically meaningful metamorphic map of the Grenville Province.

The above remarks are clearly not intended as an overview of Grenville metamorphic history. Our aim is to highlight the major regional metamorphic regimes, and to give impetus for new detailed metamorphic studies. The reader is referred to the seminal works by Davidson (1998a, 1995) and Rivers (1997), and references therein, for comprehensive reviews of the geology and tectonic history of the Grenville Province, as well as to other recent syntheses focussing on the Grenvillian terranes of Labrador (Gower 1996), Quebec (Hocq 1994), Ontario (Easton 1992, 2000b, Carr et al. 2000), and the Adirondacks (McLelland et al. 1996).

\section{ACKOWLEDGEMENTS}

The compilation of the new metamorphic map of the Canadian Shield would not have been possible without the considerable contributions of many colleagues from the GSC, provincial surveys, and universities, who willingly shared their knowledge and regional geological expertise. We are very grateful to Terry Houlahan for his cartographic expertise and assistance during this project, as well as his perseverance through the process of converting a portion of the Arc-Info map to journalsize figures. Katherine Venance assisted with compilation of the Shield metamorphic map, Pierre Brouillette, with the Grenville metamorphic map, and Dianne Paul, with preparation of the map legend. Luc LePage and Deborah Lemko helped to prepare Figure 1.

\section{REFERENCES}

Brown, M. (1993): P-T-t evolution of orogenic belts and the causes of regional metamorphism. J. Geol. Soc., London 150, 227-241.

Carmichael, D.M., Moore, J.M., Jr. \& Skippen, G.B. (1978): Isograds around the Hastings metamorphic "low". Geol. Assoc. Can. - Mineral. Assoc. Can. (Toronto), Field Trip Guidebook, 324-346.

CARR, S.D., EASton, R.M., JAMIESON, R.A. \& CUlShaw, N.G. (2000): Geologic transect across the Grenville Orogen of Ontario and New York. Can. J. Earth Sci. 37, 193-216.
Childe, F., Doig, R. \& GariéPy, C. (1993): Monazite as a metamorphic chronometer, south of the Grenville Front, western Quebec. Can. J. Earth Sci. 30, 1056-1065.

Connelly, J.N. \& Heaman, L.M. (1993): U-Pb geochronological constraints on the tectonic evolution of the Grenville Province, western Labrador. Precamb. Res. 63, 123-142.

Corrigan, D., Culshaw, N.G. \& Mortensen, K.J. (1994): Pre-Grenvillian evolution and Grenvillian overprinting of the Parautochthonous Belt in Key Harbour, Ontario: U-Pb and field constraints. Can. J. Earth Sci. 31, 583-596.

\& HANMER, S. (1997): Anorthosites and related granitoids in the Grenville orogen: a product of convective thinning of the lithosphere? Geology 25, 61-64.

RiVERs, T. \& DUNNING, G. (2000): U-Pb constraints for the plutonic and tectonometamorphic evolution of Lake Melville terrane, Labrador and implications for basement reworking in the northeastern Grenville Province. Precamb. Res. 99, 65-90.

Corriveau, L. \& Van Breemen, O. (2000): Docking of the Central Metasedimentary Belt to Laurentia in geon 12: evidence from the 1.17-1.16 Ga Chevreuil intrusive suite and host gneisses, Québec. Can. J. Earth Sci. 37, 253-269.

DAVIDSON, A. (1990): Evidence for eclogite metamorphism in the southwestern Grenville Province. Geol. Surv. Can., Pap. 90-1C, 113-118.

(1995): A review of the Grenville orogen in its North American type area. J. Aust. Geol. Geophys. 16, 3-24.

(1998a): An overview of the Grenville Province geology, Canadian Shield. Geol. Surv. Can., Geol. Can. 7, 207-270

(1998b): Geological map of the Grenville Province, Canada and adjacent parts of the United States of America. Geol. Surv. Can., Map 1947A (scale 1:2 000 000).

Carmichael, D.M. \& Pattison, D.R.M. (1990): Metamorphism and geodynamics of the southwestern Grenville Province, Ontario. Int. Geol. Correlation Program, Project 235-304, Field Trip Guidebook 1.

EAston, R.M. (1992): The Grenville Province. In Geology of Ontario. Ont. Geol. Surv., Spec. Vol. 4(2), 713-904.

(2000a): Metamorphism of the Canadian Shield, Ontario, Canada. I. The Superior Province. Can. Mineral. 38, 287-317.

(2000b): Metamorphism of the Canadian Shield, Ontario, Canada. II. Proterozoic metamorphic history. Can. Mineral. 38, 319-344.

Evans, B.W. (1990): Phase relations of epidote-blueschists. Lithos 25, 3-23. 
Fraser, J.A. \& HeYwood, W.W., eds. (1978): Metamorphism in the Canadian Shield. Geol. Surv. Can., Pap. 78-10.

\& MAZURSKI, M.A. (1978): Metamorphic map of the Canadian Shield. Geol. Surv. Can., Map 1475A (scale 1:3 500 000).

Friedman, R.M. \& Martignole, J. (1995): Mesoproterozoic sedimentation, magmatism, and metamorphism in the southern part of the Grenville Province: U-Pb geochronological constraints. Can. J. Earth Sci. 32, 2103-2144.

Froese, E. (1997): Metamorphism in the Weldon Bay - Syme Lake area, Manitoba. Geol. Surv. Can., Pap. 1997-E, $35-44$.

Gower, C.F. (1996): The evolution of the Grenville Province in eastern Labrador, Canada. In Precambrian Crustal Evolution in the North Atlantic Region (T.S. Brewer, ed.). Geol. Soc., Spec. Publ. 112, 197-218.

Heaman, L.M., Loveridge, W.D., Schärer, U. \& TUCKER, R.D. (1991): Grenvillian magmatism in the eastern Grenville Province, Canada. Precamb. Res. 51, 315-336.

HocQ, M. (1994): La province de Grenville. In Géologie du Québec. Ministère des Ressources Naturelles du Québec, Rapp. MM-94-01, 75-94.

INDARES, A. \& DunNING, G.R. (1997): Coronitic metagabbro and eclogite from the Grenville Province of western Quebec: interpretation of $\mathrm{U}-\mathrm{Pb}$ geochronology and metamorphism. Can. J. Earth Sci. 34, 891-901.

Cox, R., Gale, D. \& Connelly, J. (1998): High-pressure, high-temperature rocks from the base of thick continental crust: geology and age constraints from the Manicouagan Imbricate Zone, eastern Grenville Province. Tectonics 17, 426-440.

Ketchum, J., Jamieson, R.A., Heaman, L.M., Culshaw, N.G. \& KROGH, T.E. (1994): $1.45 \mathrm{Ga}$ granulites in the southwestern Grenville Province: geologic setting, P-T conditions, and U-Pb geochronology. Geology 22, 215-218.

Krogh, T.E. (1994): Precise U-Pb ages for Grenvillian and pre-Grenvillian thrusting of Proterozoic and Archean metamorphic assemblages in the Grenville Front tectonic zone, Canada. Tectonics 13, 963-982.
Martignole, J. (1996): Tectonic setting of anorthositic complexes of the Grenville Province, Canada. In Petrology and Geochemistry of Magmatic Suites of Rocks in the Continental and Oceanic Crusts. A Volume Dedicated to Professor Jean Michot (D. Demaiffe, ed.). Université Libre de Bruxelles and Royal Museum for Central Africa (Tervuren).

MACHAdO, N. \& IndARES, A. (1994): The Wakeham terrane: a Mesoproterozoic terrestrial rift in the eastern part of the Grenville Province. Precamb. Res. 68, 291-306.

Mclelland, J., Daly, J.S. \& Mclelland, J.M. (1996): The Grenville orogenic cycle (ca. 1350-1000 Ma): an Adirondack perspective. Tectonophys. 265, 1-28.

Rivers, T. (1997): Lithotectonic elements of the Grenville Province: review and tectonic implications. Precamb. Res. 86, 117-154.

Martignole, J., Gower, C.F. \& Davidson, A. (1989): New tectonic divisions of the Grenville Province, southeast Canadian Shield. Tectonics 8, 63-84.

Scott, D.J., Machado, N., HANMER, S. \& GariéPy, C. (1993): Dating ductile deformation using U-Pb geochronology: examples from the Gilbert River Belt, Grenville Province, Labrador, Canada. Can. J. Earth Sci. 30, 1458-1469.

Stern, R.A. \& Berman, R.G. (2000): Monazite U-Pb and $\mathrm{Th}-\mathrm{Pb}$ geochronology by ion microprobe, with an application to in-situ dating of an Archean metasedimentary rock. Chem. Geol. (in press).

Wasteneys, H.A., Kamo, S.L., Moser, D., Krogh, T.E., GOWER, C.F. \& OwEN, J.V. (1997): U-Pb geochronological constraints on the geological evolution of the Pinware terrane and adjacent areas, Grenville Province, southeast Labrador, Canada. Precamb. Res. 81, 101-128.

Williams, M.L., Jercinovic, M.J. \& Terry, M.P. (1999): Age mapping and dating of monazite on the electron microprobe; deconvoluting multistage tectonic histories. Geology 27, 1023-1026.

Zwart, H.J. (1973) Metamorphic Map of Europe (scale $1: 2,500,000)$. Subcommission for the Cartography of the Metamorphic Belts of the World. UNESCO, Paris, France.

Received May 10, 2000. 
